\title{
Lead-Free Perovskite Single Crystals: A Brief Review
}

\author{
Xianfang Zhou ${ }^{1,+}$, Yansong Wang ${ }^{2,+}$, Chuangye Ge ${ }^{3,+}$, Bin Tang ${ }^{2}$, Haoran Lin ${ }^{4}$, Xintao Zhang ${ }^{5, *}$, Yun Huang ${ }^{1}$, \\ Quanyao Zhu ${ }^{1, *}$ and Hanlin $\mathrm{Hu}^{4, *}$
}

1 School of Materials Science and Engineering, Wuhan University of Technology, Wuhan 430070, China; 257508@whut.edu.cn (X.Z.); huangyun_wh@whut.edu.cn (Y.H.)

2 Department of Materials Science and Engineering, Southern University of Science and Technology, Shenzhen 518055, China; 2031184@mail.sustech.edu.cn (Y.W.); tangb@sustech.edu.cn (B.T.)

3 Postdoctoral Innovation Practice Base, Hoffman Institute of Advanced Materials, Shenzhen Polytechnic, 7098 Liuxian Blvd, Nanshan District, Shenzhen 518055, China; gcy_xfz@szpt.edu.cn

4 Hoffman Institute of Advanced Materials, Shenzhen Polytechnic, 7098 Liuxian Blvd, Nanshan District, Shenzhen 518055, China; hlin@szpt.edu.cn

5 Department of Sports Medicine and Rehabilitation, Peking University Shenzhen Hospital, Shenzhen 518036, China

* Correspondence: 1182@pkuszh.com (X.Z.); cglamri@whut.edu.cn (Q.Z.); hanlinhu@szpt.edu.cn (H.H.)

+ The authors contribute equally to this work.

check for updates

Citation: Zhou, X.; Wang, Y.; Ge, C.; Tang, B.; Lin, H.; Zhang, X.; Huang, Y.; Zhu, Q.; Hu, H. Lead-Free Perovskite Single Crystals: A Brief Review. Crystals 2021, 11, 1329. https:// doi.org/10.3390/cryst11111329

Academic Editors: Shujun Zhang and Luisa De Marco

Received: 13 September 2021

Accepted: 28 October 2021

Published: 31 October 2021

Publisher's Note: MDPI stays neutral with regard to jurisdictional claims in published maps and institutional affiliations.

Copyright: (C) 2021 by the authors. Licensee MDPI, Basel, Switzerland. This article is an open access article distributed under the terms and conditions of the Creative Commons Attribution (CC BY) license (https:/ / creativecommons.org/licenses/by/ $4.0 /)$.

\begin{abstract}
Lead-free perovskites have received remarkable attention because of their nontoxicity, low-cost fabrication, and spectacular properties including controlled bandgap, long diffusion length of charge carrier, large absorption coefficient, and high photoluminescence quantum yield. Compared with the widely investigated polycrystals, single crystals have advantages of lower trap densities, longer diffusion length of carrier, and extended absorption spectrum due to the lack of grain boundaries, which facilitates their potential in different fields including photodetectors, solar cells, X-ray detectors, light-emitting diodes, and so on. Therefore, numerous research focusing on the novel properties, preparation methods, and remarkable progress in applications of lead-free perovskite single crystals (LFPSCs) has been extensively studied. In this review, the current advancements of LFPSCs are briefly summarized, including the synthesis approaches, compositional and interfacial engineering, and stability of several representative systems of LFPSCs as well as the reported practical applications. Finally, the critical challenges which limit the performance of LFPSCs, and their inspiring prospects for further developments are also discussed.
\end{abstract}

Keywords: lead-free perovskites; single crystal; synthesis; photovoltaic application

\section{Introduction}

As a striking material, lead halide perovskites $\left(\mathrm{APbX}_{3}\right)$ have made unprecedented progress in various fields, such as photodetectors, solar cells, $\mathrm{X}$-ray detectors, light emitting diodes, lasers, transistors, and so on [1-6]. The merits of low-cost solution processing and remarkable optoelectronic properties, including tunable bandgap, long carrier lifetime and carrier diffusion length, large absorption coefficient, give lead halide perovskites great potential in the photovoltaic power generation field [7-9]. Single-junction perovskite solar cells have realized a certified power conversion efficiency (PCE) of $25.5 \%$, which is comparable to that of silicon-based solar cells [10]. In terms of light emitting, perovskites exhibit a narrow full width at half maximum, high photoluminescence quantum yield (PLQY), and wide color gamut [11]. Meanwhile, photodetectors, transistors, and lasers are also developed rapidly.

However, the severe toxicity and chronic degrading of lead $(\mathrm{Pb})$, the aqueous solubility may cause the contamination of ground water, and the poor stability when exposed to oxygen, heat, moisture and UV light, has retarded the expanded applications of lead halide perovskites [12-14]. Although numerous nontoxic elements have been reported as dopants, 
the residual $\mathrm{Pb}$ may still present environmental risk. Hence, the development of low-toxic lead-free perovskites is of great significant to replace the classic $\mathrm{APbX}_{3}$ [15]. Meanwhile, in comparison with polycrystalline perovskites and low-dimension perovskites, perovskite single crystals (PSCs) show excellent optoelectronic properties due to their continuous and unbroken crystal lattices [16], the absence of grain boundaries leads to lower trap densities, longer length for carrier diffusion, and extended absorption spectrum [17-19]. Therefore, research of LFPSCs has promoted the enhancement of perovskite materials, and the current high-quality LFPSCs play critical roles in abundant optoelectronic devices. LFPSCs materials are a series of compounds with a general chemical formula of $\mathrm{A}_{\mathrm{x}} \mathrm{B}_{\mathrm{y}} \mathrm{X}_{\mathrm{z}}(\mathrm{x}, \mathrm{y}, \mathrm{z}$ is up to the structural dimensionality), where $\mathrm{A}$ represents an organic or inorganic cation such as $\mathrm{MA}\left(\mathrm{CH}_{3} \mathrm{NH}_{3}\right), \mathrm{FA}\left(\mathrm{HC}\left(\mathrm{NH}_{2}\right)_{2}, \mathrm{Cs}, \mathrm{Rb}, \mathrm{B}\right.$ represents a metal cation $(\mathrm{Sn} / \mathrm{Sb} / \mathrm{Bi} / \mathrm{Pd} / \mathrm{In} / \mathrm{Ti} / \mathrm{Pt} / \mathrm{Au} \mathrm{Cu} / \mathrm{Ag})$, and $\mathrm{X}$ represents halide anion $(\mathrm{Cl} / \mathrm{Br} / \mathrm{I})$. In the metal halide octahedra, B-cation stay at the center of the octahedral, and six $\mathrm{X}$-anions are situated at the six corners, which can grow three-dimensional (3D), two-dimensional (2D), one-dimensional (1D), or zero-dimensional (0D) crystal structures [20,21]. The dimensionality of the perovskite crystal structures mainly depends on the size of the cations and should also fulfill the requirement of Goldschmidt tolerance factor $(t)$,

$$
\mathrm{t}=\frac{r_{A}+r_{X}}{\sqrt{2} \times\left(r_{B}+r_{X}\right)}
$$

where, $r_{\mathrm{A}}, r_{\mathrm{B}}$, and $r_{\mathrm{X}}$ are the ionic radius of the A-site, B-site, and halide site, respectively. LFPSCs can be classified into four categories based on their crystal structure and the valency of the $\mathrm{B}$ cation: (i) divalent metal cation perovskites: $\mathrm{ABX}_{3}$ (B is +2 oxidation state, $B=S n / G e / Y b)$ or layered perovskites $A_{2} A_{n-1}^{\prime} B_{n} X_{3 n+1} ;\left(A^{\prime}=\right.$ long chained organic cations that do not fit in the $\left[\mathrm{BX}_{6}\right]^{4-}$ cavity); (ii) trivalent metal cation perovskites: $\mathrm{A}_{3} \mathrm{~B}_{2 \times 9}$ ( $\mathrm{B}$ is +3 oxidation state, $\mathrm{B}=\mathrm{Sb} / \mathrm{Bi}$ ); (iii) tetravalent metal cation perovskites: $\mathrm{A}_{2} \mathrm{BX}_{6}$ ( $\mathrm{B}$ is +4 oxidation state) $(\mathrm{B}=\mathrm{Sn} / \mathrm{Ge} / \mathrm{Pd} / \mathrm{Pt})$; and (iv) double perovskites: $\mathrm{A}_{2} \mathrm{BB}^{\prime} \mathrm{X}_{6}$ ( $\mathrm{B}$ is +1 while $\mathrm{B}^{\prime}$ is +3 oxidation states) ( $\mathrm{B}$ is $\mathrm{Au} / \mathrm{Ag} / \mathrm{ACu}$; $\mathrm{B}^{\prime}$ is $\mathrm{In} / \mathrm{Bi} / \mathrm{Sb}$ ) $[12,22]$.

Though a number of efforts have been devoted to develop various LFPCs, a lack of comprehensive understanding towards the synthesis methods, properties, and the device performance still restrict their practical application. To promote the development of LFPSCs, we mainly focus on summarizing the up-to-date advancement of several representative PSCs and their applications in photodetectors, photovoltaics solar cells, X-ray detectors, light-emitting diodes (LEDs), and other devices [23]. To be specific, various systems including replacement of $\mathrm{Pb}$-based perovskites, perovskite-like derivate and double perovskites are presented. Strategies for development and stabilization of LFPSCs lattice, improvement of optoelectronic performance based on fabrication process, compositional, structural, and interfacial engineering are also discussed. In the end, we provide the challenges and further prospects of LFPSC.

\section{Various Systems of Pb-Free Single Crystal}

In general, lead halide perovskites possess a universal chemical formula of $\mathrm{APbX}_{3}$, where A represents an organic/inorganic cation including $\mathrm{Cs}^{+}$, methylammonium (MA), formamidinium (FA) or their mixture, and $\mathrm{X}$ represents a halide anion which consists of $\mathrm{Cl}^{-}, \mathrm{Br}^{-}, \mathrm{I}^{-}$, or their mixture. In terms of structure, $\mathrm{Pb}^{2+}$ cations are separated by six neighbor $\mathrm{X}$-site anions to bulid $\mathrm{Pb}-\mathrm{X}$ octahedrons, which corner-share with each other to constitute the main frame and $\mathrm{A}^{+}$intercalates the voids [24]. The replacement of $\mathrm{Pb}^{2+}$ with lead-free ions results in both the deformation in nanoscale structure and the conversion of properties because of the differences in chemical valence and ion size [23]. Therefore, LFPSCs exhibit plenty of novelty and diversity, we discussed several typical LFPSCs in this section and summarized in Table 1, along with the schematic diagrams of synthesis methods as shown in Figure 1. 


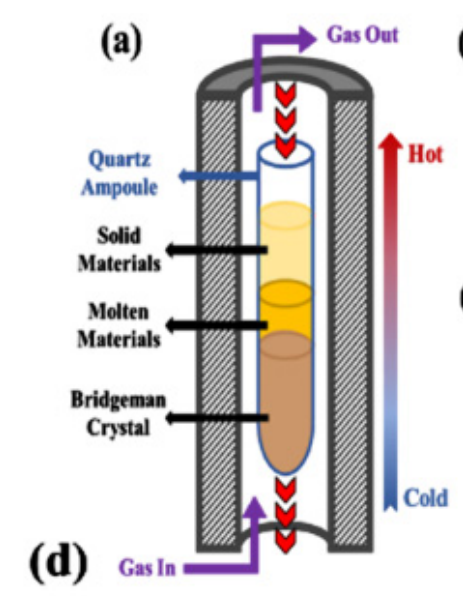

(b)
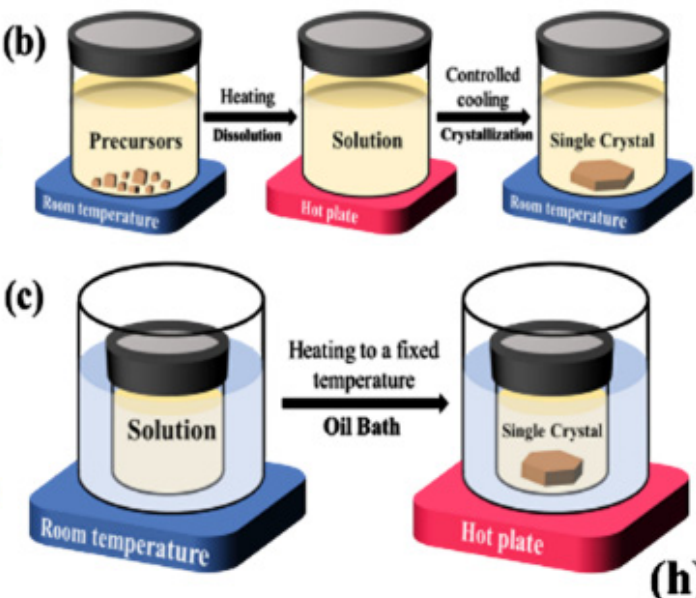

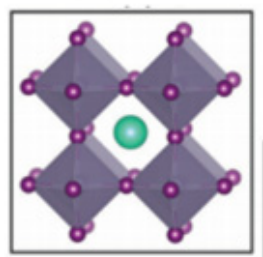

$\mathrm{AB}(\mathrm{II}) \mathrm{X}_{3}$ (e)

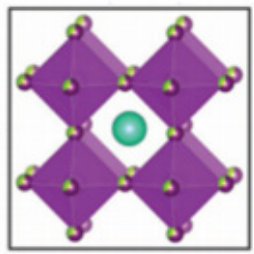

$\mathrm{AB}(\mathrm{Ch}, \mathrm{X})_{3}$
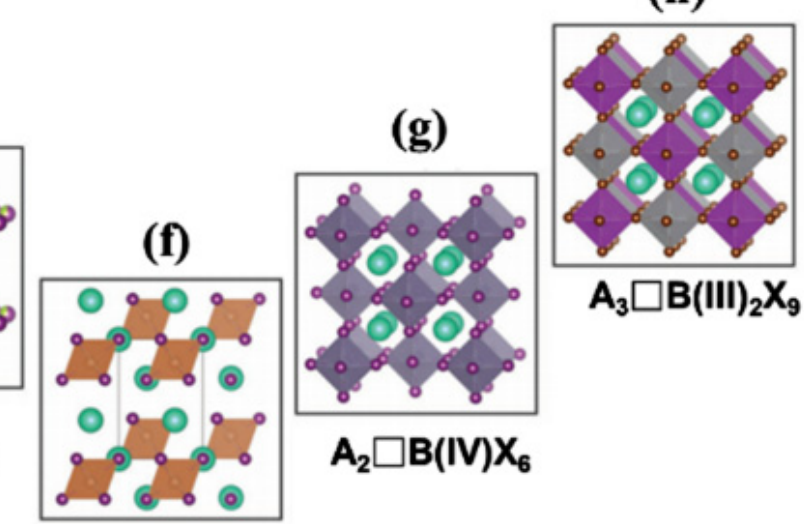

$\mathrm{A}_{2} \mathrm{~B}(\mathrm{I}) \mathrm{B}(\mathrm{II}) \mathrm{X}_{3}$

Figure 1. Schematic diagrams of synthesis methods of LFPSCs. (a) Bridgeman method. (b) Coolinginduced crystallization method. (c) Inverse temperature crystallization. (d-h) Typical crystal structures of LFPSCs. Reprinted (adapted) with permission from Reference 12. Copyright 2020 Elsevier Ltd. Reprinted (adapted) with permission from Reference [22]. Copyright 2021 American Chemical Society.

\subsection{Sn Based Halide Perovskites}

Attributed to the same valence and similar properties with $\mathrm{Pb}^{2+}, \mathrm{Sn}^{2+}$ is seen as a crucial candidate to form lead-free perovskites without the sacrifice of the excellent performance. The first Sn-based halide perovskite single crystals were synthesized in 1974 for $\mathrm{CsSnX}_{3}$ [25]. In 2012, Chung et al. prepared $\mathrm{CsSnI}_{3}$ single crystals using a modified vertical Bridgman technique with refined crystal structure and optical properties [26]. Due to the crystal structure transformation from $\alpha$-phase to $\gamma$-phase during the preparation of $\mathrm{CsSnI}_{3}$, the crystal configuration of $\mathrm{CsSnI}_{3}$ is not cubic symmetry, but the stable $\gamma$-phase $\mathrm{CsSnI}_{3} \mathrm{SC}$ (direct bandgap $=1.3 \mathrm{eV}$ ) at room temperature, showing a p-type semiconductor behavior with a carrier concentration and a hole mobility of $\approx 10^{17} \mathrm{~cm}^{-3}$ and $\approx 585 \mathrm{~cm}^{2} \mathrm{~V}^{-1} \mathrm{~s}^{-1}$, respectively. A similar result has been reported in $\mathrm{FASnI}_{3}$ perovskite single crystals by Kahmann et al. [27]. Yao et al. developed a novel process called local temperature reduction induced crystallization to prepare $110 \mu$ m-thick MASnI $_{3}$ single crystal wafer which shows good crystallinity and great orientation as well as gives a bandgap of $1.21 \mathrm{eV}$. In addition, $\mathrm{MASnI}_{3}$ wafer displays an extended absorption spectrum and red-shifted photoluminescence (PL) peak compared with $\mathrm{MAPbI}_{3} \mathrm{SC}$ [28]. The introduction of appropriate dopants is considered as an effective way to improve performance, Zhang et al. successfully synthesized the Bi-doped two-dimension(2D) LFPSCs of $\mathrm{PEA}_{2} \mathrm{Sn}_{1-x} \mathrm{Bi}_{x} \mathrm{Br}_{4+\mathrm{x}}$ which exhibited unique crystal structure and layered surface morphology with the undoped one, controllable PL behaviors were obtained by controlling addition of Bi dopants at the same time [29]. 


\subsection{Bi/Sb Based Halide Perovskites}

Trivalent ions such as $\mathrm{Bi}^{3+}$ and $\mathrm{Sb}^{3+}$ are also considered as the alternatives for LFPSCs. Generally, $B^{3+}$ can form a perovskite-like derivate- $A_{3} B_{2} X_{9}$, with $0 D$ or $2 D$ crystal structures. The initial exploration started by Lehner and co-workers in 2015 [30]. They found A and $X$ atoms are closest-packed while $B$ atoms occupy $2 / 3$ voids of the octahedral $X_{6}$, and the crystal structures of $\mathrm{A}_{3} \mathrm{~B}_{2} \mathrm{X}_{9}$ can be classified into two typical types: cubic close-packing and hexagonal close-packing of $\mathrm{A}$ and $\mathrm{X}$ atoms. Changes of $\mathrm{A}$ cation lead to significant differences in structural configurations and properties. To be specific, $\mathrm{Cs}_{3} \mathrm{Bi}_{2} \mathrm{I}_{9}$ single crystal tends to form a $0 \mathrm{D}$ configuration attributed to the isolated $\left[\mathrm{Bi}_{2} \mathrm{X}_{9}\right]$ structures, which is resulted from the face-sharing [ $\mathrm{BiX}_{6}$ ] octahedron. By contrast, $\mathrm{K}_{3} \mathrm{Bi}_{2} \mathrm{I}_{9}$ and $\mathrm{Rb}_{3} \mathrm{Bi}_{2} \mathrm{I}_{9}$ tend to generate layer-like 2D structures. Another popular trivalent ion is $\mathrm{Sb}^{3+}$. McCall and co-workers synthesized $\mathrm{Cs}_{3} \mathrm{Bi}_{2} \mathrm{I}_{9}$ and $\mathrm{Rb}_{3} \mathrm{Bi}_{2} \mathrm{I}_{9} \mathrm{SC}$ s by the Bridgman method and characterized their crystal structures by SCs $\mathrm{X}$-ray diffraction, showing $\left[\mathrm{SbI}_{6}\right]$ octahedrons and isolating alkali ions for both of them. For optoelectronic properties, they display broad PL emission from 1.75 to $2.05 \mathrm{eV}$ with two peaks located at 1.96 and $1.92 \mathrm{eV}$, respectively [31]. Besides that, these scholars have made a further investigation on other derivatives, after optimizing the synthesis of single crystal, they implemented the photo-response to observe visible laser emission of $\mathrm{Cs}_{3} \mathrm{Bi}_{2} \mathrm{I}_{9}$ for the first time. All SCs showed ambipolar response to Am $\alpha$-particles irradiation with spectra for both electron and hole collection configurations, and it is worth noting that $\mathrm{Cs}_{3} \mathrm{Bi}_{2} \mathrm{I}_{9}$ and $\mathrm{Cs}_{3} \mathrm{Sb}_{2} \mathrm{I}_{9}$ showed a superb potential for radiation detection [32].

\subsection{Other Metals Based Perouskites}

Researchers have also developed some other metal-based PSCs, such as from indium, copper. In the work of Zhou et al., they employed a slow-cooling crystal growth approach by blending $\mathrm{CsBr}$ and $\mathrm{InBr}_{3}$ in $\mathrm{HBr}$ at $130{ }^{\circ} \mathrm{C}$ for $0.5 \mathrm{~h}$ [33]. After cooling down to room temperature, $0 \mathrm{D} \mathrm{Cs} \mathrm{InBr}_{5}: \mathrm{H}_{2} \mathrm{O}$ was obtained with a size of around $2 \mathrm{~mm}$. It shows a $0 \mathrm{D}$ orthorhombic crystal structure where the $\left[\mathrm{InBr}_{5} \mathrm{O}\right]_{4}{ }^{-}$octahedrons were separated by two $\mathrm{Cs}^{+}$-cations. It also displays a bright red luminescence peak at $695 \mathrm{~nm}$ with a PLQY of $33 \%$ under excitation of $365 \mathrm{~nm}$. Other $0 \mathrm{D}\left(\mathrm{C}_{4} \mathrm{H}_{14} \mathrm{~N}_{2}\right)_{2} \mathrm{InBr}_{10}$ PSCs were synthesized within several minutes by adding $\mathrm{InBr}_{3}$ solution (dissolved in $\mathrm{HBr}$ acid) into a mixture of diethylamine and $\mathrm{HBr}$ at $0{ }^{\circ} \mathrm{C}$ [34]. The $\mathrm{In}-\mathrm{Br}$ polyhedrons were separated by the $\left(\mathrm{C}_{4} \mathrm{H}_{14} \mathrm{~N}_{2}\right)^{2+}$-cations to produce a 0-D perovskite-like structure. It exhibits an abrupt absorption from 350 to $600 \mathrm{~nm}$ and a broad band emission from $500 \mathrm{~nm}$ and near-infrared region attributes to the structural distortion of $\left[\mathrm{InBr}_{6}\right]^{3-}$ octahedral units leading to the formation of self-trapped exciton (STE) states, confirmed also by computational study.

Lin and his co-workers prepared perovskite-like $1 \mathrm{D} \mathrm{CsCu} \mathrm{C}_{2} \mathrm{I}_{3}$ by anti-solvent vaporassisted crystallization method where they dissolved equimolar $\mathrm{CuI}$ and CsI (DMF:DMSO = 4:1) at $60^{\circ} \mathrm{C}$ with an atmosphere of methanol and kept for a few days [35]. A colorless $\mathrm{CsCu}_{2} \mathrm{I}_{3} \mathrm{SCs}$ with orthorhombic crystal structure was developed, showing a broad band white light emission spectrum and PLQY of $15.7 \%$ due to the recombination by STE states. To obtain high quality 0D PSCs of (MA) ${ }_{4} \mathrm{Cu}_{2} \mathrm{Br}_{6}, \mathrm{DMF}$ (solvent of $\mathrm{MABr}$ and CuBr solution) was slowly evaporated at $50{ }^{\circ} \mathrm{C}$ for 2 days [36]. Due to the STE states induced photo-generated excitons relax, showing a bright green emission (peaked at $524 \mathrm{~nm}$ ) with a high PLQY of $93 \%$ and an ultra-long PL life time up to $120 \mu \mathrm{s}$.

\subsection{Halide Double Perovskites}

Apart from single B-site ions-based lead-free perovskite, double perovskites with a formula of $A_{2} B^{\prime} B^{\prime \prime} X_{6}$ have been investigated due to their excellent performance [37-39]. Pan et al. used a solution-process approach to obtain double perovskite $\mathrm{Cs}_{2} \mathrm{AgBiBr}_{6}$ single crystals, where centers of the metal bromide octahedron are occupied by alternate $\mathrm{Bi}^{3+}$ and $\mathrm{Ag}^{+}$. They proposed the presence of cations disorder during the growth process, resulting in the destroyed symmetry of double perovskite. Thermal annealing and surface treatment could eliminate these defects and improve the crystal resistivity effectively [40]. 
After that, numerous researchers have accomplished research on $\mathrm{Cs}_{2} \mathrm{AgBiBr}_{6}$ [41-44], in the work of Zhang et al., the resistivity of the $\mathrm{Cs}_{2} \mathrm{AgBiBr}_{6}$ was larger than $10^{10} \Omega \mathrm{cm}$, the Fermi level was estimated to be $0.788 \mathrm{eV}$ above the valence band and the two near bandgap energies were $1.917 \mathrm{eV}$ and $2.054 \mathrm{eV}$, respectively [41]. Keshavarz and co-workers employed alkali substitution to tune the structures and properties of $\mathrm{Cs}_{2} \mathrm{AgBiBr}_{6}$ double perovskites. The fundamental lifetime of carrier recombination at room temperature attained a three-fold increase with the band gap remaining unchanged [44]. Furthermore, Yin et al. synthesized $\mathrm{Cs}_{2} \mathrm{AgIn}_{\mathrm{x}} \mathrm{Fe}_{1-\mathrm{x}} \mathrm{Cl}_{6}(0<\mathrm{x}<1)$ perovskite SCs employing a simple hydrothermal method, which exhibited a broadband absorbance from 450 to $800 \mathrm{~nm}$ and a huge enhancement of PLQY [45]. Luo et al. prepared high quality $\mathrm{Cs}_{2} \mathrm{AgInCl}_{6}$ SCs by space-confined hydrothermal method, achieving an ultra-low trap density of $(8.6 \pm 1.9) \times 10^{8} \mathrm{~cm}^{-3}$ and mobility of $3.31 \mathrm{~cm}^{2} \cdot \mathrm{V}^{-1} \cdot \mathrm{s}^{-1}$, respectively. In addition, they proposed that oxygen or oxygen-containing functional groups could alter the superficial composition and physical properties [46].

Table 1. Summary of structural parameters and synthesis methods of representative LFPSCs.

\begin{tabular}{|c|c|c|c|c|c|c|}
\hline Ion & Perovskite & $\begin{array}{c}\text { Bandgap } \\
(\mathrm{eV})\end{array}$ & $\begin{array}{l}\text { Crystal } \\
\text { System }\end{array}$ & Dimension & Synthesis & Ref. \\
\hline $\mathrm{Sn}^{2+}$ & $\mathrm{CsSnI}_{3}$ & 1.31 & Orthorhombic & $3 \mathrm{D}$ & Bridgeman Method & [26] \\
\hline $\mathrm{Sn}^{2+}$ & $\alpha-\mathrm{FASnI}_{3}$ & $\mathrm{~N} / \mathrm{A}$ & Cubic & $3 \mathrm{D}$ & $\mathrm{N} / \mathrm{A}$ & [27] \\
\hline $\mathrm{Sn}^{2+}$ & $\beta-\mathrm{FASnI}_{3}$ & $\mathrm{~N} / \mathrm{A}$ & Tetragonal & $3 \mathrm{D}$ & $\mathrm{N} / \mathrm{A}$ & [27] \\
\hline $\mathrm{Sn}^{2+}$ & $\gamma-\mathrm{FASnI}_{3}$ & $\mathrm{~N} / \mathrm{A}$ & Tetragonal & $3 \mathrm{D}$ & $\mathrm{N} / \mathrm{A}$ & [27] \\
\hline $\mathrm{Sn}^{2+}$ & $\mathrm{MASnI}_{3}$ & 1.21 & Cubic & $3 \mathrm{D}$ & Cooling-induced crystallization method & [28] \\
\hline $\mathrm{Sn}^{2+}$ & $\mathrm{PEA}_{2} \mathrm{SnBr}_{4}$ & 2.6 & Monoclinic & $2 \mathrm{D}$ & Cooling-induced crystallization method & [29] \\
\hline $\mathrm{Bi}^{3+}$ & $\mathrm{Rb}_{3} \mathrm{Bi}_{2} \mathrm{I}_{9}$ & 2.1 & Monoclinic & $2 \mathrm{D}$ & Bridgeman Method & {$[30]$} \\
\hline $\mathrm{Bi}^{3+}$ & $\mathrm{Cs}_{3} \mathrm{Bi}_{2} \mathrm{I}_{9}$ & $1.9 / 2.06$ & Hexagonal & OD & Bridgeman Method & {$[30,31]$} \\
\hline $\mathrm{Sb}^{3+}$ & $\mathrm{Rb}_{3} \mathrm{Sb}_{2} \mathrm{I}_{9}$ & 2.03 & Monoclinic & $2 \mathrm{D}$ & Bridgeman Method & [31] \\
\hline $\mathrm{Sb}^{3+}$ & $\mathrm{Cs}_{3} \mathrm{Sb}_{2} \mathrm{I}_{9}$ & 1.89 & Hexagonal & $2 \mathrm{D}$ & Bridgeman Method & {$[31,32]$} \\
\hline \multirow{2}{*}{$\mathrm{N} / \mathrm{A}$} & \multirow{2}{*}{$\mathrm{Cs}_{2} \mathrm{AgBiBr}_{6}$} & 2.1 & \multirow{2}{*}{ Cubic } & \multirow{2}{*}{$3 \mathrm{D}$} & Inverse temperature crystallization method & [40] \\
\hline & & 2.25 & & & Cooling-induced crystallization method & [42] \\
\hline $\mathrm{N} / \mathrm{A}$ & $\mathrm{Cs}_{2} \mathrm{AgInCl}_{6}$ & 3.2 & Cubic & $3 \mathrm{D}$ & Cooling-induced crystallization method & {$[46]$} \\
\hline
\end{tabular}

\section{Applications}

LFPSCs possess numerous fascinating optoelectronic properties in practical applications, as shown in Figure 1. Even if there is still a certain gap between lead-free and lead-based PSCs, several applications of LFPSCs have attracted attention recently. Herein, the reported achievements of applications using LFPSCs, such as photodetectors, solar cells, X-ray detectors, light emitting diodes, and other applications (Figure 2), are discussed.

\subsection{Photodetectors}

Photodetectors capture optical signals and convert them into electrical signals instantaneously, which have been widely employed in abundant fields. The key factors of excellent photodetectors can be summarized as fast responding speed, high photocurrent intensity, and low detectivity. The research of Dou et al. was the pioneer in applications of photodetectors using perovskite materials [5]. Tang and co-workers firstly fabricated LFPSC based UV photodetector with $\mathrm{Cs}_{2} \mathrm{AgInCl}_{6}$, under the continuous altering of $365 \mathrm{~nm}$ monochromatic illumination, the photodetectors showed photocurrent and dark current with a bias of $5 \mathrm{~V}$. The photocurrent was increased from $5 \times 10^{-9} \mathrm{~A}$ in vacuum to $8 \times 10^{-9} \mathrm{~A}$ in air, attributing to the oxygen-induced enhancement of surface conductance. The response time is $0.97 \mathrm{~ms}$ in vacuum, $2.11 \mathrm{~ms}$ in air. Meanwhile, a high on/off 
ratio ( $\sim 500)$ and a high detectivity ( $10^{12}$ Jones) were obtained [46]. Li et al. fabricated photodetectors with $\mathrm{Cs}_{3} \mathrm{Bi}_{2} \mathrm{I}_{9}$ single crystal and polycrystal with a unified structure of $\mathrm{Au} / \mathrm{Cs}_{3} \mathrm{Bi}_{2} \mathrm{I}_{9} / \mathrm{Au}$, the calculated trap density of single crystal was $5.7 \times 10^{12} \mathrm{~cm}^{-3}$, which is much lower that of polycrystal $\left(1.5 \times 10^{15} \mathrm{~cm}^{-3}\right)$, the carrier mobility of single crystal was estimated as $1.7 \times 10^{-2} \mathrm{~cm}^{2} \mathrm{~s}^{-1} \mathrm{~V}^{-1}$, which is $3.8 \times 10^{4}$ folds higher than that for polycrystal $\left(4.4 \times 10^{-7} \mathrm{~cm}^{2} \mathrm{~s}^{-1} \mathrm{~V}^{-1}\right)$. In addition, the $\mathrm{Cs}_{3} \mathrm{Bi}_{2} \mathrm{I}_{9}$ single crystal photodetector exhibited a high photo-response ON-OFF ratio as 11,000 and outstanding stability [47]. Similarly, Dang et al. assembled $\mathrm{Cs}_{2} \mathrm{AgBiBr}_{6}$ PSC-based photodetectors, where the photodetection performance was investigated with various electrodes including $\mathrm{Ag}$, $\mathrm{Au}$, and $\mathrm{Al}$ under different wavelength illumination [48]. At $5 \mathrm{~V}$ bias, the $\mathrm{Cs}_{2} \mathrm{AgBiBr}_{6} \mathrm{SC}$ device displayed a responsivity of $0.9 \mathrm{~mA} \mathrm{~W}^{-1}$ in air and $0.92 \mathrm{~mA} \mathrm{~W}^{-1}$ in a vacuum under $400 \mathrm{~nm}$ illumination. The detectivity was estimated to be $1.38 \times 10^{9}$ and $2.66 \times 10^{9}$ Jones, respectively, the on/off ratio was estimated as 42 and 153, respectively. All results suggest that $\mathrm{Cs}_{2} \mathrm{AgBiBr}_{6}$ SC-based photodetector with Ag electrodes exhibit excellent photoresponse. Liu et al. reported a blue light photodetector with a structure of $\mathrm{Si} / \mathrm{SiO}_{2} / \mathrm{Cs}_{3} \mathrm{Sb}_{2} \mathrm{Br}_{9} / \mathrm{Au}$, the device possessed low dark current $\left(2.4 \times 10^{-12} \mathrm{~A}\right)$ and impressive photocurrent $\left(3.1 \times 10^{-8} \mathrm{~A}\right)$ at a bias of $6 \mathrm{~V}$ under dark condition and illuminated by $480 \mathrm{~nm}$ light, the response and recovery time was $0.2 \mathrm{~ms}$ and $3 \mathrm{~ms}$ respectively [49]. Compared with other lead-free perovskite-based photodetectors, Zheng et al. fabricated a nanoflake photodetector demonstrating a response speed of $24 / 48 \mathrm{~ms}$ [50]. Table 2 summarizes some relevant works published on this topic.

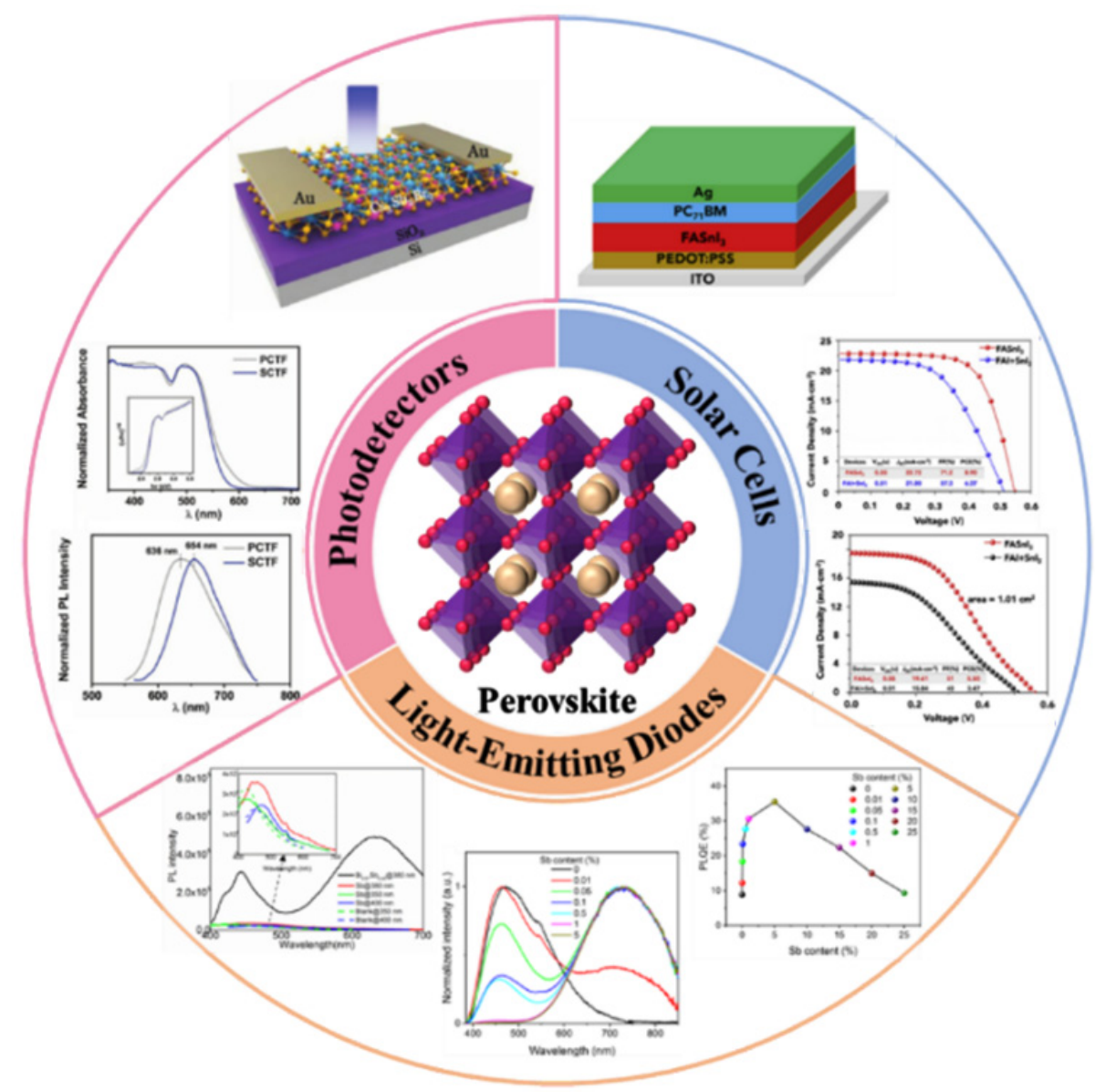

Figure 2. Illustration of various remarkable properties of LFPSCs in practical applications, including photodetectors, X-ray detectors, and light-emitting diodes. Reprinted (adapted) with permission from Reference [23]. Copyright 2021 WILEY-VCH Verlag GmbH \& Co. KGaA, Weinheim. 
Table 2. Photodetection parameters of LFPSCs based devices.

\begin{tabular}{ccccc}
\hline LEPSC & Responsivity & Detectivity (Jones) & ON-OFF Ratio & Ref. \\
\hline $\mathrm{Cs}_{2} \mathrm{AgInCl}_{6}$ & $0.013 \mathrm{~A} \mathrm{~W}^{-1}$ & $9.60 \times 10^{11}$ & $\mathrm{NA}$ & {$[46]$} \\
\hline $\mathrm{Cs}_{3} \mathrm{Bi}_{2} \mathrm{I}_{9}$ & $7.2 \times 10^{-3} \mathrm{~A} \mathrm{~W}^{-1}$ & $1.0 \times 10^{11}$ & $\mathrm{NA}$ & {$[47]$} \\
\hline $\mathrm{Cs}_{2} \mathrm{AgBiBr}_{6}$ & $0.92 \mathrm{~A} \mathrm{~W}^{-1}$ & $2.66 \times 10^{9}$ & 153 & {$[48]$} \\
\hline $\mathrm{Cs}_{2} \mathrm{AgBiBr}_{6}$ & $0.9 \mathrm{~mA} \mathrm{~W}^{-1}$ & $1.38 \times 10^{9}$ & 42 & {$[48]$} \\
\hline $\mathrm{Cs}_{3} \mathrm{Bi}_{2} \mathrm{I}_{9}$ & $2.29 \mathrm{~A} \mathrm{~W}^{-1}$ & $3.77 \times 10^{12}$ & $\mathrm{NA}$ & {$[49]$} \\
\hline
\end{tabular}

\subsection{Solar Cells}

Since Kojima et al. firstly applied perovskite materials in solar cells with a PCE of $3.81 \%$ in 2009 [51], perovskite solar cells have been expected to be an alternative to solve the urgent problems of energy shortage and environmental pollution. Although numerous significant achievements of high-performance lead-based perovskite solar cells have been reported in recent years [4,52-54], including research on single crystals [55,56], poor stability and high toxicity are their urgent concerns [57]. For LFPSCs, the toxicity is suppressed by the replacement of lead, and the absence of moisture-sensitive grain boundaries leads to favorable stability, meanwhile extra properties including low trap density, dense structure, and low ion migration are obtained [58]. Several strategies employing single crystals have been proven to benefit the efficiency and stability, nevertheless, there is rarely a report on LFPSC film-based solar cells, and the photovoltaic parameters of some relevant works are summarized in Table 3. He et al. fabricated the device using synthesized $\mathrm{FASnI}_{3}$ single crystals as precursors, which possessed high purity, low defect density, and excellent stability in the air [59]. The authors demonstrated that re-dissolved single crystals forming solution effectively prevents the oxidation of $\mathrm{Sn}^{2+}$ by reducing impurities and moisture. The single crystal precursors-based films showed smooth morphology and exhibited larger and more uniform grains than conventional films. The PCE of device was $8.9 \%$ and $5.5 \%$ for spin-coated solar cells and large-scale printed cells, respectively. In addition, $\mathrm{FASnI}_{3}$ single crystal precursors-based devices retained a higher percentage of initial PCE than conventional devices. The precise controlling of crystallization to obtain near-single-crystalline film is also a viable approach to achieve higher performance. For instance, $\mathrm{Li}$ et al. proposed the annealing of $\mathrm{FASnI}_{3}$ assisted by phenylethyl ammonium chloride enabled to form pure-phase ordered 2D perovskite crystals with excellent vertical orientation, and the fabricated solar cells exhibited a champion PCE of $9.1 \%$ after $1500 \mathrm{~h}$ of storage under dark condition, with short-circuit current density $\left(J_{\mathrm{sc}}\right)$ of $22.06 \mathrm{~mA} \mathrm{~cm}^{-2}$, open-circuit voltage $\left(V_{\text {oc }}\right)$ of $0.59 \mathrm{~V}$, and fill factor $(\mathrm{FF})$ of $69 \%$ [60]. Shao et al. successfully deposited near-single-crystalline $\mathrm{FASnI}_{3}$ with the orthorhombic a-axis in the out-of-plane direction by mixing a trace amount of layered $2 \mathrm{D}$ tin perovskite. The corresponding devices achieved a high PCE of $9.0 \%$ [61].

Table 3. Photovoltaic Parameters of LFPSCs based solar cells devices.

\begin{tabular}{cccccc}
\hline LEPSCs & Voc $(\mathbf{V})$ & Jsc $\left(\mathbf{m A} / \mathbf{c m}^{2}\right)$ & FF & PCE (\%) & Ref. \\
\hline FASnI $_{3}$ & 0.63 & 21.60 & 74.7 & 10.17 & {$[62]$} \\
\hline FASnI $_{3}$ & 0.628 & 22.23 & 74.2 & 10.37 & {$[63]$} \\
\hline $\mathrm{FASnI}_{3}+1 \% \mathrm{EDAI}_{2}$ & 0.58 & 21.3 & 72 & 8.9 & {$[64]$} \\
\hline $\mathrm{FASnI}_{3}+5 \% \mathrm{PHCl}$ & 0.76 & 23.5 & 64 & 11.4 & {$[65]$} \\
\hline $\mathrm{CsSnI}$ & 0.86 & 23.2 & 65 & 12.96 & {$[66]$} \\
\hline$(\mathrm{FA})_{0.75}(\mathrm{MA})_{0.25} \mathrm{SnI}_{3}+10 \% \mathrm{SnF}_{2}$ & 0.61 & 21.2 & 62.7 & 8.12 & {$[67]$} \\
\hline $\mathrm{AVA}_{2} \mathrm{FA}_{\mathrm{n}-1} \mathrm{Sn}_{\mathrm{n}} \mathrm{I}_{3 \mathrm{n}+1}$ & 0.61 & 21.0 & 68 & 8.71 & {$[68]$} \\
\hline $\mathrm{PEA}_{\mathrm{x}} \mathrm{FA}_{1-\mathrm{x}} \mathrm{SnI}_{3}+\mathrm{NH}_{4} \mathrm{SC}$ & 0.94 & 17.4 & 75 & 12.4 & {$[69]$} \\
\hline
\end{tabular}




\subsection{X-ray Detectors}

X-ray detection plays an important role for scientific study, medical diagnosis, and industrial inspection [12,70]. LFPSCs can be good candidates for X-ray detection because of some unique properties including large $\mathrm{X}$-ray attenuation coefficients; a suitable bandgap ( 1.5 to $5.0 \mathrm{eV}$ ); highly crystalline with lower trap density; large bulk resistivity with less ion migration; high sensitivity and stability; and low toxicity [71,72]. The detection of $\mathrm{X}$-ray has been of great importance due to the wide applications of X-ray in various fields, and some relevant works are summarized in Table 4 on this topic. [73-76]. Liu et al. developed $\mathrm{MA}_{3} \mathrm{Bi}_{2} \mathrm{I}_{9} \mathrm{SCs}$, showing large $\mathrm{X}$-ray absorptivity, large bulk resistivity of around $4.7 \times 10^{10} \mathrm{ohm}-\mathrm{cm}$, high density of $\sim 4.1 \mathrm{~g} / \mathrm{cm}^{3}$, and high ion migration activation energy of $0.83 \mathrm{eV}$ [77]. $\mathrm{MA}_{3} \mathrm{Bi}_{2} \mathrm{I}_{9} \mathrm{SCs}$ based X-ray detector exhibited fast response of $266 \mathrm{~ms}$, high sensitivity of $872 \mathrm{mC} / \mathrm{Gy} / \mathrm{cm}^{2}$, detection limit of $31 \mathrm{nGy} / \mathrm{s}$, and good stability under ambient atmosphere. Tang et al. fabricated $\mathrm{Cs}_{2} \mathrm{AgBiBr}_{6} \mathrm{SC}$ X-ray detector s with a vertical $\mathrm{Au} / \mathrm{Cs}_{2} \mathrm{AgBiBr}_{6} / \mathrm{Au}$ structure and exposed the devices to $\mathrm{X}$-ray to investigate its performance. The gain factor, which could be regarded as the charge collection efficiency, was about 0.14 for a dose rate of $60-138.7 \mu \mathrm{Gy}_{\text {air }} \mathrm{s}^{-1}$, similar to that of photodiode structure $\mathrm{MAPbBr}_{3} \mathrm{X}$-ray detectors (0.16). It was worth noting that when increasing the dose rate, the gain factor gradually decreased due to the enhanced carrier filling into shallower traps under higher radiation. Benefitting from low ionization energy, the detectors achieved complete absorption and a sensitivity of $105 \mu \mathrm{C} \mathrm{Gyair}{ }^{-1} \mathrm{~cm}^{-2}$ at a driving voltage of $50 \mathrm{~V}$, which was four times higher than that of commercial $\alpha$-Se detectors [40]. Based on these studies, they optimized the growth process of $\mathrm{Cs}_{2} \mathrm{AgBiBr}_{6}$ employing precisely controlled cooling synthesis to obtain superior single crystals exhibiting a high resistivity with narrow distribution range from $6.10 \times 10^{9}$ to $3.31 \times 10^{10} \Omega \mathrm{cm}$, by comparison, the resistivity of reference ranged from $6.04 \times 10^{7}$ to $5.61 \times 10^{9} \Omega \mathrm{cm}$. The as-prepared X-ray detectors with optimum SCs had a sensitivity of $1974 \mu \mathrm{C} \mathrm{Gyair}{ }^{-1} \mathrm{~cm}^{-2}$ under $50 \mathrm{~V}$ [78]. Liu et al. fabricated a highly sensitive and stable X-ray detector with $0 \mathrm{D} \mathrm{MA}_{3} \mathrm{Bi}_{2} \mathrm{I}_{9} \mathrm{SC}$ s for the first time. A precursor refinement strategy was adopted to synthesize high-quality LFPSCs, consisting of face-sharing $\left(\mathrm{BiI}_{6}\right)^{3-}$ octahedrons where the voids between the layers were filled with the $\mathrm{MA}^{+}$, in which the formed $\left(\mathrm{Bi}_{2} \mathrm{I}_{9}\right)^{3-}$ are spatially isolated by two $\mathrm{MA}^{+}$, resulting in a $0 \mathrm{D}$ crystal structure. Attributed to such a special $0 \mathrm{D}$ structure, the electrontrap density of $\mathrm{MA}_{3} \mathrm{Bi}_{2} \mathrm{I}_{9}$ single crystals was calculated to be $1.2 \times 10^{10} \mathrm{~cm}^{-3}$ and the hole-trap density was $7.5 \times 10^{10} \mathrm{~cm}^{-3}$, the resistivity was measured as $3.74 \times 10^{10} \Omega \mathrm{cm}$. Therefore, the corresponding detector showed a high sensitivity $\left(1947 \mu \mathrm{C} \mathrm{Gy} \mathrm{yir}^{-1} \mathrm{~cm}^{-2}\right.$ ) and fast response speed (23.3/31.4 ms) [79]. Other than 3D LFPSCs, 2D PEA-Cs $2 \mathrm{AgBiBr}_{6}$ and $(\mathrm{BA})_{2} \mathrm{CsAgBiBr}_{7} \mathrm{SCs}$ based $\mathrm{X}$-ray detectors also demonstrated high sensitivity of $288.8 \mathrm{mC} /$ Gyair $/ \mathrm{cm}^{2}$ and $4.2 \mathrm{mC} /$ Gyair $/ \mathrm{cm}^{2}$, respectively [80]. PEA-Cs $\mathrm{AgBiBr}_{6} \mathrm{SCs}$ displayed sensitivity of $18.1 \mathrm{mC} /$ Gyair $/ \mathrm{cm}^{2}$ which was approximately twice higher than that of pristine $\mathrm{Cs}_{2} \mathrm{AgBiBr}_{6} \mathrm{SC}$. Benefitting from the higher formation energy encountered in these SCs, they displayed enhanced photostability due to the low defect density and low defect migration.

Table 4. X-ray detection parameters of LFPSCs based devices.

\begin{tabular}{|c|c|c|c|c|}
\hline LEPSCs & $\begin{array}{l}\mu \tau \text { Product } \\
\left(\mathrm{cm}^{2} \mathrm{~V}^{-1}\right)\end{array}$ & $\begin{array}{c}\text { Sensitivity } \\
\left(\mu \mathrm{C} \cdot \text { Gyair }^{-1} \cdot \mathrm{cm}^{-2}\right)\end{array}$ & $\begin{array}{c}\text { Detection limit } \\
\text { (nGyairs }^{-1} \text { ) }\end{array}$ & Ref. \\
\hline $\mathrm{Cs}_{2} \mathrm{AgBiBr}_{6}$ & $6.3 \times 10^{-3}$ & 316.8 & 59.7 & [40] \\
\hline $\mathrm{Cs}_{2} \mathrm{AgBiBr}_{6}$ & $5.95 \times 10^{-3}$ & 1974 & 226.2 & [78] \\
\hline $\mathrm{MA}_{3} \mathrm{Bi}_{2} \mathrm{I}_{9}$ & NA & 1947 & 83 & [79] \\
\hline $\mathrm{Cs}_{3} \mathrm{Bi}_{2} \mathrm{I}_{9}$ & $7.97 \times 10^{-4}$ & 1652.3 & 130 & [81] \\
\hline$(\mathrm{BA})_{2} \mathrm{CsAgBiBr}_{7}$ & $1.21 \times 10^{-3}$ & 4.2 & NA & [80] \\
\hline$\left(\mathrm{H}_{2} \mathrm{MDAP}\right) \mathrm{BiI}_{5}$ & NA & 1.0 & NA & [82] \\
\hline
\end{tabular}




\subsection{Light-Emitting Diodes}

Another important optoelectronic application of perovskites is light-emitting diodes (LED) because of their PLQY, tunable band gap, and facile solution preparation. For LFPSCs, low-dimensional halide perovskites have attracted remarkable attention for their spectacular photoluminescence properties and chemical stability, also, the doping strategies have been widely adopted to enable or balance multiple emission centers [83-85]. In 2019, a $\left(\mathrm{C}_{8} \mathrm{NH}_{12}\right)_{4} \mathrm{Bi}_{0.57} \mathrm{Sb}_{0.43} \mathrm{Br}_{7} \cdot \mathrm{H}_{2} \mathrm{O}$ SCs was synthesized and showed ultra-broadband emission spectrum between 400 and $850 \mathrm{~nm}$, with a PLQY value increased from $0.7 \%$ $\left(\left(\mathrm{C}_{8} \mathrm{NH}_{12}\right)_{4} \mathrm{BiBr}_{7} \cdot \mathrm{H}_{2} \mathrm{O}\right)$ to $4.5 \%$ [83]. $\mathrm{Li}$ et al. synthesized $\left(\mathrm{C}_{8} \mathrm{NH}_{12}\right)_{6} \mathrm{InBr}_{9} \cdot \mathrm{H}_{2} \mathrm{O}$ single crystals exhibiting weak broadband red emission and a PLQY value of $8.85 \%$ because of the strong exciton-phonon interaction induced STEs. Doping $\mathrm{Sb}^{3+}$ at $\mathrm{In}^{3+}$ sites can effectively optimize the band gap structure and enhance ultra-broadband red emission, the PLQY value was increased up to $23.36 \%$ via controlling the Sb doping level [84].

\subsection{Humidity Sensor and Field-Effect Transistors}

Besides the above-mentioned applications, $\mathrm{Pb}$-free PSCs were also employed into other promising applications. Zhou et al. prepared a Pb-free $0 \mathrm{D} \mathrm{Cs}_{2} \mathrm{InBr}_{5} \cdot \mathrm{H}_{2} \mathrm{O}$ PSC with a broad red luminescence centered at $695 \mathrm{~nm}$ and a high PLQY up to $33 \%$, resulting from the deformations of charge carriers via STE states [33]. It exhibits different emission in a moisture-containing condition with good structural- and photo-stability. A PL humidity sensor was fabricated based on switchable dual emission corresponding to the hydrated and dehydrated states, showing good recyclability and fast response time. This pioneering work establishes a foothold for the utilization of $\mathrm{Pb}$-free perovskite in humidity detection and also demonstrates the advantages of exploring novel applications for these $\mathrm{Pb}$-free perovskite materials.

Luo et al. fabricated a field effect transistor using solution-processed $\mathrm{Cs}_{2} \mathrm{SnI}_{6}$ nanobelts under ambient conditions using a $\mathrm{SiO}_{2}$ coated silicon wafer substrate and pre-patterned $\mathrm{Au}$ as the metal electrode [46]. P-type $\mathrm{Cs}_{2} \mathrm{SnI}_{6}$ film-based devices possess high $\mathrm{I}_{\mathrm{ON}} / \mathrm{I}_{\mathrm{OFF}}$ ratio under photoexcitation with hole mobility and hole concentration of $20.2 \mathrm{~cm}^{2} / \mathrm{V} / \mathrm{s}$, $9.1 \times 10^{18} \mathrm{~cm}^{-3}$, respectively.

\section{Challenges and Prospects}

In general, LFPSCs have drawn extensive interests due to their environmentally friendly features without involving toxic lead, and excellent optoelectronic properties resulted from the absence of grain boundaries. In the past few years, enormous efforts have been devoted to various explorations of LFPSCs such as optimizing synthesis and doping strategies to produce high-quality single crystals with attractive properties including long carrier lifetimes and carrier diffusion lengths, tunable bandgap, large absorption coefficient, low trap density. Even though several considerable achievements of applications have been reported, the further development of LFPSCs is still facing unsolved problems which may impede the expansion of applications. The current challenges and prospects of LFPSCs are summarized as follows:

(1) The performance of LFPSCs extremely depends on the synthesis methods, hence the exploration of controllable and reliable synthesis to yield stable and high-quality single crystals is necessary to be focused on, with economic and environmental factors under consideration. Moreover, the precise control of thickness and size could be effective approaches to enhance the performance of different devices. For these LFPSCs with low dimensionality crystal structure and wide bandgap, they usually show limited charge transportation and collection and narrow absorption range of the visible range. It is worthy to develop increased dimensional materials to gain a full understanding of the fundamentals and applications of these LFPSCs.

(2) The doping strategies, employed to improve properties, are universal in the research of LFPSCs, but the specific enhancement mechanism has not been thoroughly studied. The intensive study of dopants contributes to obtaining tunable and enhanced 
single crystals. Most LFPSCs possess wide bandgap which exhibited a narrow range absorption of the solar spectrum. It is important to design more materials with favorable bandgaps and study the structure-property correlation systematically by tuning their bandgaps through halide exchange. For practical applications, large-area fabrication is as important as low-cost, high responsivity, and long-term stability for devices. Preparing high-quality large-scale LFPSCs film with controlled thickness and size for optoelectronic applications remains an unconquered challenge. Moreover, as does the improvement in the optimization and integration of perovskite devices into practical device application.

(3) The reproducibility of LFPSCs based devices remains a huge challenge. Almost all the reported devices are fabricated based on lab-scale. They demonstrated batch-tobatch variations, and most of their results cannot be reproduced. The properties of the synthesized materials highly depended on the operator and condition for processing, storage. There are no standardized protocols for synthesis, characterization, and testing to follow.

(4) The large thickness of LFPSC along the direction of carrier transportation may lead to low current density, while the fabricating technologies of devices also suppress the PCE of solar cells. The existence of migration of ions and vacancies could be a major factor for the decrement of the device performance by retarding the charge carrier transportation. The ion migration can also affect the crystal structure due to the activation energy dependence on the crystal. In addition, various channels based on thermal energy and local polarization have been identified as fast and slow ion migration pathways.

(5) Stability of LEFPSs is another important issue. The degradation of perovskite structures happened when exposed to humidity, oxygen, heating, and UV light illumination as we observed in case of $\mathrm{Pb}$ based perovskites. The degradation mechanisms are still unclear. Therefore, huge efforts should be devoted to improve crystal stability as well as maintain their excellent photophysical and chemical properties.

These issues have raised challenges for facilitating the applications of LFPSCs, nevertheless, considering the remarkable optoelectronic properties and stability, we believe LFPSCs have a bright future in optoelectronic applications.

Author Contributions: Writing-original draft preparation, X.Z. (Xianfang Zhou), Y.W. and C.G.; Conceptualization and investigation, B.T., H.L.; methodology, Y.H.; writing-review and editing, X.Z. (Xintao Zhang), Q.Z. and H.H. All authors have read and agreed to the published version of the manuscript.

Funding: The financial support from National Natural Science Foundation of China (62004129; 22005202; 51472189; 52002301; 21802097) and Shenzhen Science and Technology Innovation Commission (Project No. JCYJ20200109105003940) is gratefully acknowledged, and this work was also supported by Shenzhen Polytechnic. This study is supported by Post-Doctoral Foundation Project of Shenzhen Polytechnic 6021330007K.

Institutional Review Board Statement: Not applicable.

Informed Consent Statement: Not applicable.

Data Availability Statement: Data is contained within the article.

Conflicts of Interest: The authors declare that they have no known competing financial interest or personal relationships that could have appeared to influence the work reported in this paper.

\section{References}

1. Zhao, Q.; Hazarika, A.; Chen, X.; Harvey, S.P.; Larson, B.W.; Teeter, G.R.; Liu, J.; Song, T.; Xiao, C.; Shaw, L.; et al. High efficiency perovskite quantum dot solar cells with charge separating heterostructure. Nat. Commun. 2019, 10, 2842. [CrossRef] [PubMed]

2. Wei, Y.; Cheng, Z.; Lin, J. An overview on enhancing the stability of lead halide perovskite quantum dots and their applications in phosphor-converted LEDs. Chem. Soc. Rev. 2019, 48, 310-350. [CrossRef] [PubMed]

3. Wang, H.; Kim, D.H. Perovskite-based photodetectors: Materials and devices. Chem. Soc. Rev. 2017, 46, 5204-5236. [CrossRef]

4. Jeong, J.; Kim, M.; Seo, J.; Lu, H.; Ahlawat, P.; Mishra, A.; Yang, Y.; Hope, M.A.; Eickemeyer, F.T.; Kim, M.; et al. Pseudo-halide anion engineering for alpha-FAPbI 3 perovskite solar cells. Nature 2021, 592, 381-385. [CrossRef] 
5. $\quad$ Dou, L.; Yang, Y.M.; You, J.; Hong, Z.; Chang, W.H.; Li, G.; Yang, Y. Solution-processed hybrid perovskite photodetectors with high detectivity. Nat. Commun. 2014, 5, 5404. [CrossRef] [PubMed]

6. Yin, W.-J.; Shi, T.; Yan, Y. Unusual defect physics in $\mathrm{CH}_{3} \mathrm{NH}_{3} \mathrm{PbI}_{3}$ perovskite solar cell absorber. Appl. Phys. Lett. 2014, 104, 063903. [CrossRef]

7. Wang, Q.; Wang, X.; Yang, Z.; Zhou, N.; Deng, Y.; Zhao, J.; Xiao, X.; Rudd, P.; Moran, A.; Yan, Y.; et al. Efficient sky-blue perovskite light-emitting diodes via photoluminescence enhancement. Nat. Commun. 2019, 10, 5633. [CrossRef]

8. Shamsi, J.; Urban, A.S.; Imran, M.; De Trizio, L.; Manna, L. Metal Halide Perovskite Nanocrystals: Synthesis, Post-Synthesis Modifications, and Their Optical Properties. Chem. Rev. 2019, 119, 3296-3348. [CrossRef]

9. Lin, K.; Xing, J.; Quan, L.N.; de Arquer, F.P.G.; Gong, X.; Lu, J.; Xie, L.; Zhao, W.; Zhang, D.; Yan, C. Perovskite light-emitting diodes with external quantum efficiency exceeding 20 per cent. Nature 2018, 562, 245-248. [CrossRef]

10. Min, H.; Lee, D.Y.; Kim, J.; Kim, G.; Lee, K.S.; Kim, J.; Paik, M.J.; Kim, Y.K.; Kim, K.S.; Kim, M.G.; et al. Perovskite solar cells with atomically coherent interlayers on $\mathrm{SnO}_{2}$ electrodes. Nature 2021, 598, 444-450. [CrossRef]

11. Luo, J.; Hu, M.; Niu, G.; Tang, J. Lead-free halide perovskites and perovskite variants as phosphors toward light-emitting applications. ACS Appl. Mater. Interfaces 2019, 11, 31575-31584. [CrossRef]

12. Bhaumik, S.; Ray, S.; Batabyal, S.K. Recent advances of lead-free metal halide perovskite single crystals and nanocrystals: Synthesis, crystal structure, optical properties, and their diverse applications. Mater. Today Chem. 2020, 18, 100363. [CrossRef]

13. Jiang, H.; Kloc, C. Single-crystal growth of organic semiconductors. MRS Bull. 2013, 38, 28-33. [CrossRef]

14. Deng, Y.; Xiao, Z.; Huang, J. Light-Induced Self-Poling Effect on Organometal Trihalide Perovskite Solar Cells for Increased Device Efficiency and Stability. Adv. Energy Mater. 2015, 5, 1500721. [CrossRef]

15. Akkerman, Q.A.; Raino, G.; Kovalenko, M.V.; Manna, L. Genesis, challenges and opportunities for colloidal lead halide perovskite nanocrystals. Nat. Mater. 2018, 17, 394-405. [CrossRef] [PubMed]

16. Song, Y.; Bi, W.; Wang, A.; Liu, X.; Kang, Y.; Dong, Q. Efficient lateral-structure perovskite single crystal solar cells with high operational stability. Nat. Commun. 2020, 11, 274. [CrossRef] [PubMed]

17. Jing, L.; Cheng, X.; Yuan, Y.; Du, S.; Ding, J.; Sun, H.; Zhan, X.; Zhou, T. Design Growth of Triangular Pyramid MAPbBr3 Single Crystal and Its Photoelectric Anisotropy between (100) and (111) Facets. J. Phys. Chem. C 2019, 123, 10826-10830. [CrossRef]

18. Yang, C.; El-Demellawi, J.K.; Yin, J.; Velusamy, D.B.; Emwas, A.-H.M.; El-Zohry, A.M.; Gereige, I.; AlSaggaf, A.; Bakr, O.M.; Alshareef, H.N.; et al. MAPbI3 Single Crystals Free from Hole-Trapping Centers for Enhanced Photodetectivity. ACS Energy Lett. 2019, 4, 2579-2584. [CrossRef]

19. Chen, Y.; He, M.; Peng, J.; Sun, Y.; Liang, Z. Structure and Growth Control of Organic-Inorganic Halide Perovskites for Optoelectronics: From Polycrystalline Films to Single Crystals. Adv. Sci. 2016, 3, 1500392. [CrossRef]

20. Chakraborty, S.; Xie, W.; Mathews, N.; Sherburne, M.; Ahuja, R.; Asta, M.; Mhaisalkar, S.G. Rational Design: A High-Throughput Computational Screening and Experimental Validation Methodology for Lead-Free and Emergent Hybrid Perovskites. ACS Energy Lett. 2017, 2, 837-845. [CrossRef]

21. Giustino, F.; Snaith, H.J. Toward Lead-Free Perovskite Solar Cells. ACS Energy Lett. 2016, 1, 1233-1240. [CrossRef]

22. Tailor, N.K.; Kar, S.; Mishra, P.; These, A.; Kupfer, C.; Hu, H.; Awais, M.; Saidaminov, M.; Dar, M.I.; Brabec, C.; et al. Advances in Lead-Free Perovskite Single Crystals: Fundamentals and Applications. ACS Mater. Lett. 2021, 3, 1025-1080. [CrossRef]

23. Zhao, S.; Cai, W.; Wang, H.; Zang, Z.; Chen, J. All-Inorganic Lead-Free Perovskite(-Like) Single Crystals: Synthesis, Properties, and Applications. Small Methods 2021, 5, 2001308. [CrossRef]

24. Akkerman, Q.A.; Manna, L. What defines a halide perovskite? ACS Energy Lett. 2020, 5, 604-610. [CrossRef] [PubMed]

25. Scaife, D.E.; Weller, P.F.; Fisher, W.G. Crystal preparation and properties of cesium tin (II) trihalides. J. Solid State Chem. 1974, 9 , 308-314. [CrossRef]

26. Chung, I.; Song, J.-H.; Im, J.; Androulakis, J.; Malliakas, C.D.; Li, H.; Freeman, A.J.; Kenney, J.T.; Kanatzidis, M.G. CsSnI 3 : Semiconductor or metal? High electrical conductivity and strong near-infrared photoluminescence from a single material. High hole mobility and phase-transitions. J. Am. Chem. Soc. 2012, 134, 8579-8587. [CrossRef] [PubMed]

27. Kahmann, S.; Nazarenko, O.; Shao, S.; Hordiichuk, O.; Kepenekian, M.; Even, J.; Kovalenko, M.V.; Blake, G.R.; Loi, M.A. Negative Thermal Quenching in $\mathrm{FASnI}_{3}$ Perovskite Single Crystals and Thin Films. ACS Energy Lett. 2020, 5, 2512-2519. [CrossRef]

28. Yao, Z.; Yang, Z.; Liu, Y.; Zhao, W.; Zhang, X.; Liu, B.; Wu, H.; Liu, S. Local temperature reduction induced crystallization of MASnI3 and achieving a direct wafer production. RSC Adv. 2017, 7, 38155-38159. [CrossRef]

29. Zhang, R.; Mao, X.; Cheng, P.; Yang, Y.; Yang, S.; Wumaier, T.; Deng, W.; Han, K. Bismuth doped lead-free two-dimensional tin based halide perovskite single crystals. J. Energy Chem. 2019, 36, 1-6. [CrossRef]

30. Lehner, A.J.; Fabini, D.H.; Evans, H.A.; Hébert, C.-A.; Smock, S.R.; Hu, J.; Wang, H.; Zwanziger, J.W.; Chabinyc, M.L.; Seshadri, R. Crystal and Electronic Structures of Complex Bismuth Iodides $\mathrm{A}_{3} \mathrm{Bi}_{2} \mathrm{I}_{9}(\mathrm{~A}=\mathrm{K}, \mathrm{Rb}, \mathrm{Cs})$ Related to Perovskite: Aiding the Rational Design of Photovoltaics. Chem. Mater. 2015, 27, 7137-7148. [CrossRef]

31. McCall, K.M.; Stoumpos, C.C.; Kostina, S.S.; Kanatzidis, M.G.; Wessels, B.W. Strong Electron-Phonon Coupling and Self-Trapped Excitons in the Defect Halide Perovskites $\mathrm{A}_{3} \mathrm{M}_{2} \mathrm{I}_{9}(\mathrm{~A}=\mathrm{Cs}, \mathrm{Rb} ; \mathrm{M}=\mathrm{Bi}, \mathrm{Sb})$. Chem. Mater. 2017, 29, 4129-4145. [CrossRef]

32. McCall, K.M.; Liu, Z.; Trimarchi, G.; Stoumpos, C.C.; Lin, W.; He, Y.; Hadar, I.; Kanatzidis, M.G.; Wessels, B.W. $\alpha$-Particle Detection and Charge Transport Characteristics in the $\mathrm{A}_{3} \mathrm{M}_{2} \mathrm{I}_{9}$ Defect Perovskites $(\mathrm{A}=\mathrm{Cs}, \mathrm{Rb} ; \mathrm{M}=\mathrm{Bi}, \mathrm{Sb})$. ACS Photonics 2018, 5 , 3748-3762. [CrossRef] 
33. Zhou, L.; Liao, J.; Huang, Z.; Wei, J.; Wang, X.; Li, W.; Chen, H.; Kuang, D.; Su, C. A Highly Red-Emissive Lead-Free Indium-Based Perovskite Single Crystal for Sensitive Water Detection. Angew. Chem. Int. Ed. 2019, 58, 5277-5281. [CrossRef] [PubMed]

34. Zhou, L.; Liao, J.; Huang, Z.; Wei, J.; Wang, X.; Chen, H.; Kuang, D. Intrinsic Self-Trapped Emission in 0D Lead-Free $\left(\mathrm{C}_{4} \mathrm{H}_{14} \mathrm{~N}_{2}\right)_{2} \mathrm{In}_{2} \mathrm{Br}_{10}$ Single Crystal. Angew. Chem. Int. Ed. 2019, 58, 15435-15440. [CrossRef]

35. Lin, R.; Guo, Q.; Zhu, Q.; Zhu, Y.; Zheng, W.; Huang, F. All-Inorganic $\mathrm{CsCu}_{2} \mathrm{I}_{3}$ Single Crystal with High-PLQY ( $\left.\approx 15.7 \%\right)$ Intrinsic White-Light Emission via Strongly Localized 1D Excitonic Recombination. Adv. Mater. 2019, 31, 1905079. [CrossRef] [PubMed]

36. Peng, H.; Yao, S.; Guo, Y.; Zhi, R.; Wang, X.; Ge, F.; Tian, Y.; Wang, J.; Zou, B. Highly Efficient Self-Trapped Exciton Emission of a (MA) ${ }_{4} \mathrm{Cu}_{2} \mathrm{Br}_{6}$ Single Crystal. J. Phys. Chem. Lett. 2020, 11, 4703-4710. [CrossRef]

37. Slavney, A.H.; Hu, T.; Lindenberg, A.M.; Karunadasa, H.I. A Bismuth-Halide Double Perovskite with Long Carrier Recombination Lifetime for Photovoltaic Applications. J. Am. Chem. Soc. 2016, 138, 2138-2141. [CrossRef]

38. Wu, C.; Zhang, Q.; Liu, Y.; Luo, W.; Guo, X.; Huang, Z.; Ting, H.; Sun, W.; Zhong, X.; Wei, S. The dawn of lead-free perovskite solar cell: Highly stable double perovskite $\mathrm{Cs}_{2} \mathrm{AgBiBr}_{6}$ film. Adv. Sci. 2018, 5, 1700759. [CrossRef] [PubMed]

39. Ning, W.; Gao, F. Structural and functional diversity in lead-free halide perovskite materials. Adv. Mater. 2019, $31,1900326$. [CrossRef] [PubMed]

40. Pan, W.; Wu, H.; Luo, J.; Deng, Z.; Ge, C.; Chen, C.; Jiang, X.; Yin, W.-J.; Niu, G.; Zhu, L.; et al. Cs 2 AgBiBr $_{6}$ single-crystal X-ray detectors with a low detection limit. Nat. Photonics 2017, 11, 726-732. [CrossRef]

41. Zhang, Z.; Yang, G.; Zhou, C.; Chung, C.-C.; Hany, I. Optical and electrical properties of all-inorganic $\mathrm{Cs}_{2} \mathrm{AgBiBr}_{6} \mathrm{double}$ perovskite single crystals. RSC Adv. 2019, 9, 23459-23464. [CrossRef]

42. Steele, J.A.; Pan, W.; Martin, C.; Keshavarz, M.; Debroye, E.; Yuan, H.; Banerjee, S.; Fron, E.; Jonckheere, D.; Kim, C.W.; et al. Photophysical Pathways in Highly Sensitive $\mathrm{Cs}_{2} \mathrm{AgBiBr}_{6}$ Double-Perovskite Single-Crystal X-Ray Detectors. Adv. Mater. 2018, 30, e1804450. [CrossRef]

43. Zhang, Z.; Chung, C.-C.; Huang, Z.; Vetter, E.; Seyitliyev, D.; Sun, D.; Gundogdu, K.; Castellano, F.N.; Danilov, E.O.; Yang, G. Towards radiation detection using $\mathrm{Cs}_{2} \mathrm{AgBiBr}_{6}$ double perovskite single crystals. Mater. Lett. 2020, 269, 127667. [CrossRef]

44. Keshavarz, M.; Debroye, E.; Ottesen, M.; Martin, C.; Zhang, H.; Fron, E.; Küchler, R.; Steele, J.A.; Bremholm, M.; Van de Vondel, J. Tuning the Structural and Optoelectronic Properties of $\mathrm{Cs}_{2} \mathrm{AgBiBr}_{6}$ Double-Perovskite Single Crystals through Alkali-Metal Substitution. Adv. Mater. 2020, 32, 2001878. [CrossRef]

45. Yin, H.; Xian, Y.; Zhang, Y.; Chen, W.; Wen, X.; Rahman, N.U.; Long, Y.; Jia, B.; Fan, J.; Li, W. An Emerging Lead-Free Double-Perovskite $\mathrm{Cs}_{2} \mathrm{AgFeCl}_{6}$ : In Single Crystal. Adv. Funct. Mater. 2020, 30, 2002225. [CrossRef]

46. Luo, J.; Li, S.; Wu, H.; Zhou, Y.; Li, Y.; Liu, J.; Li, J.; Li, K.; Yi, F.; Niu, G. $\mathrm{Cs}_{2} \mathrm{AgInCl}_{6}$ double perovskite single crystals: Parity forbidden transitions and their application for sensitive and fast UV photodetectors. ACS Photonics 2018, 5, 398-405. [CrossRef]

47. Li, W.; Wang, X.; Liao, J.; Jiang, Y.; Kuang, D. Enhanced On-Off Ratio Photodetectors Based on Lead-Free $\mathrm{Cs}_{3} \mathrm{Bi}_{2} \mathrm{I}_{9} \mathrm{Single}_{\mathrm{Crystal}}$ Thin Films. Adv. Funct. Mater. 2020, 30, 1909701. [CrossRef]

48. Dang, Y.; Tong, G.; Song, W.; Liu, Z.; Qiu, L.; Ono, L.K.; Qi, Y. Interface engineering strategies towards $\mathrm{Cs}_{2} \mathrm{AgBiBr}_{6}$ singlecrystalline photodetectors with good Ohmic contact behaviours. J. Mater. Chem. C 2020, 8, 276-284. [CrossRef]

49. Liu, P.; Liu, Y.; Zhang, S.; Li, J.; Wang, C.; Zhao, C.; Nie, P.; Dong, Y.; Zhang, X.; Zhao, S.; et al. Lead-Free $\mathrm{Cs}_{3} \mathrm{Sb}_{2} \mathrm{Br}_{9} \mathrm{Sin}_{\mathrm{n}} \mathrm{e}$ Crystals for High Performance Narrowband Photodetector. Adv. Opt. Mater. 2020, 8, 2001072. [CrossRef]

50. Zheng, Z.; Hu, Q.; Zhou, H.; Luo, P.; Nie, A.; Zhu, H.; Gan, L.; Zhuge, F.; Ma, Y.; Song, H.; et al. Submillimeter and lead-free $\mathrm{Cs}_{3} \mathrm{Sb}_{2} \mathrm{Br}_{9}$ perovskite nanoflakes: Inverse temperature crystallization growth and application for ultrasensitive photodetectors. Nanoscale Horiz. 2019, 4, 1372-1379. [CrossRef]

51. Kojima, A.; Teshima, K.; Shirai, Y.; Miyasaka, T. Organometal halide perovskites as visible-light sensitizers for photovoltaic cells. J. Am. Chem. Soc. 2009, 131, 6050-6051. [CrossRef] [PubMed]

52. Han, Y.; Zhao, H.; Duan, C.; Yang, S.; Yang, Z.; Liu, Z.; Liu, S. Controlled n-Doping in Air-Stable CsPbI ${ }_{2}$ Br Perovskite Solar Cells with a Record Efficiency of $16.79 \%$. Adv. Funct. Mater. 2020, 30, 1909972. [CrossRef]

53. Jeong, M.; Choi, I.W.; Go, E.M.; Cho, Y.; Kim, M.; Lee, B.; Jeong, S.; Jo, Y.; Choi, H.W.; Lee, J. Stable perovskite solar cells with efficiency exceeding $24.8 \%$ and $0.3-\mathrm{V}$ voltage loss. Science 2020, 369, 1615-1620. [CrossRef] [PubMed]

54. Jiang, Q.; Zhao, Y.; Zhang, X.; Yang, X.; Chen, Y.; Chu, Z.; Ye, Q.; Li, X.; Yin, Z.; You, J. Surface passivation of perovskite film for efficient solar cells. Nat. Photonics 2019, 13, 460-466. [CrossRef]

55. Alsalloum, A.Y.; Turedi, B.; Zheng, X.; Mitra, S.; Zhumekenov, A.A.; Lee, K.J.; Maity, P.; Gereige, I.; AlSaggaf, A.; Roqan, I.S. Low-temperature crystallization enables $21.9 \%$ efficient single-crystal $\mathrm{MAPbI}_{3}$ inverted perovskite solar cells. ACS Energy Lett. 2020, 5, 657-662. [CrossRef]

56. Chen, Z.; Turedi, B.; Alsalloum, A.Y.; Yang, C.; Zheng, X.; Gereige, I.; AlSaggaf, A.; Mohammed, O.F.; Bakr, O.M. Single-crystal $\mathrm{MAPbI}_{3}$ perovskite solar cells exceeding 21\% power conversion efficiency. ACS Energy Lett. 2019, 4, 1258-1259. [CrossRef]

57. Ke, W.; Kanatzidis, M.G. Prospects for low-toxicity lead-free perovskite solar cells. Nat. Commun. 2019, 10, 965. [CrossRef] [PubMed]

58. Cheng, X.; Yang, S.; Cao, B.; Tao, X.; Chen, Z. Single Crystal Perovskite Solar Cells: Development and Perspectives. Adv. Funct. Mater. 2019, 30, 1905021. [CrossRef]

59. He, L.; Gu, H.; Liu, X.; Li, P.; Dang, Y.; Liang, C.; Ono, L.K.; Qi, Y.; Tao, X. Efficient anti-solvent-free spin-coated and printed Sn-perovskite solar cells with crystal-based precursor solutions. Matter 2020, 2, 167-180. [CrossRef] 
60. Li, M.; Zuo, W.-W.; Yang, Y.-G.; Aldamasy, M.H.; Wang, Q.; Cruz, S.H.T.; Feng, S.-L.; Saliba, M.; Wang, Z.-K.; Abate, A. Tin halide perovskite films made of highly oriented 2D crystals enable more efficient and stable lead-free perovskite solar cells. ACS Energy Lett. 2020, 5, 1923-1929. [CrossRef]

61. Shao, S.; Liu, J.; Portale, G.; Fang, H.; Blake, G.R.; ten Brink, G.H.; Koster, L.J.A.; Loi, M.A. Highly reproducible Sn-based hybrid perovskite solar cells with $9 \%$ efficiency. Adv. Energy Mater. 2018, 8, 1702019. [CrossRef]

62. Wu, T.; Liu, X.; He, X.; Wang, Y.; Meng, X.; Noda, T.; Yang, X.; Han, L. Efficient and stable tin-based perovskite solar cells by introducing $\pi$-conjugated Lewis base. Sci. China Chem. 2020, 63, 107-115. [CrossRef]

63. Meng, X.; Wu, T.; Liu, X.; He, X.; Noda, T.; Wang, Y.; Segawa, H.; Han, L. Highly Reproducible and Efficient FASnI 3 Perovskite Solar Cells Fabricated with Volatilizable Reducing Solvent. J. Phys. Chem. Lett. 2020, 11, 2965-2971. [CrossRef]

64. Jokar, E.; Chien, C.-H.; Fathi, A.; Rameez, M.; Chang, Y.-H.; Diau, E.W.-G. Slow surface passivation and crystal relaxation with additives to improve device performance and durability for tin-based perovskite solar cells. Energy Environ. Sci. 2018, 11, 2353-2362. [CrossRef]

65. Wang, C.; Gu, F.; Zhao, Z.; Rao, H.; Qiu, Y.; Cai, Z.; Zhan, G.; Li, X.; Sun, B.; Yu, X.; et al. Self-Repairing Tin-Based Perovskite Solar Cells with a Breakthrough Efficiency Over 11\%. Adv. Mater. 2020, 32, 1907623. [CrossRef]

66. Zhao, B.; Abdi-Jalebi, M.; Tabachnyk, M.; Glass, H.; Kamboj, V.S.; Nie, W.; Pearson, A.J.; Puttisong, Y.; Gödel, K.C.; Beere, H.E.; et al. High Open-Circuit Voltages in Tin-Rich Low-Bandgap Perovskite-Based Planar Heterojunction Photovoltaics. Adv. Mater. 2017, 29, 1604744. [CrossRef]

67. Sabba, D.; Mulmudi, H.K.; Prabhakar, R.R.; Krishnamoorthy, T.; Baikie, T.; Boix, P.P.; Mhaisalkar, S.; Mathews, N. Impact of Anionic Br-Substitution on Open Circuit Voltage in Lead Free Perovskite (CsSnI 3 -x Br x) Solar Cells. J. Phys. Chem. C 2015, 119, 1763-1767. [CrossRef]

68. Xu, H.; Jiang, Y.; He, T.; Li, S.; Wang, H.; Chen, Y.; Yuan, M.; Chen, J. Orientation Regulation of Tin-Based Reduced-Dimensional Perovskites for Highly Efficient and Stable Photovoltaics. Adv. Funct. Mater. 2019, 29, 1807696. [CrossRef]

69. Jiang, X.; Wang, F.; Wei, Q.; Li, H.; Shang, Y.; Zhou, W.; Wang, C.; Cheng, P.; Chen, Q.; Chen, L.; et al. Ultra-high open-circuit voltage of tin perovskite solar cells via an electron transporting layer design. Nat. Commun. 2020, 11, 1245. [CrossRef] [PubMed]

70. Li, Y.; Yang, T.; Xu, Z.; Liu, X.; Huang, X.; Han, S.; Liu, Y.; Li, M.; Luo, J.; Sun, Z. Dimensional Reduction of Cs ${ }_{2}$ AgBiBr $_{6}$ : A 2D Hybrid Double Perovskite with Strong Polarization Sensitivity. Angew. Chem. Int. Ed. 2020, 59, 3429-3433. [CrossRef]

71. Shi, C.; Ye, L.; Gong, Z.-X.; Ma, J.-J.; Wang, Q.-W.; Jiang, J.-Y.; Hua, M.-M.; Wang, C.-F.; Yu, H.; Zhang, Y.; et al. TwoDimensional Organic-Inorganic Hybrid Rare-Earth Double Perovskite Ferroelectrics. J. Am. Chem. Soc. 2020, 142, 545-551. [CrossRef] [PubMed]

72. Guo, W.; Liu, X.; Han, S.; Liu, Y.; Xu, Z.; Hong, M.; Luo, J.; Sun, Z. Room-Temperature Ferroelectric Material Composed of a Two-Dimensional Metal Halide Double Perovskite for X-ray Detection. Angew. Chem. Int. Ed. 2020, 59, 13879-13884. [CrossRef]

73. Wang, C.; Li, H.; Li, M.; Cui, Y.; Song, X.; Wang, Q.; Jiang, J.; Hua, M.; Xu, Q.; Zhao, K.; et al. Centimeter-Sized Single Crystals of Two-Dimensional Hybrid Iodide Double Perovskite (4,4-Difluoropiperidinium) ${ }_{4} \mathrm{AgBiI}_{8}$ for High-Temperature Ferroelectricity and Efficient X-Ray Detection. Adv. Funct. Mater. 2021, 31, 2009457. [CrossRef]

74. Yakunin, S.; Dirin, D.N.; Shynkarenko, Y.; Morad, V.; Cherniukh, I.; Nazarenko, O.; Kreil, D.; Nauser, T.; Kovalenko, M.V. Detection of gamma photons using solution-grown single crystals of hybrid lead halide perovskites. Nat. Photonics 2016, 10, 585-589. [CrossRef]

75. Wei, W.; Zhang, Y.; Xu, Q.; Wei, H.; Fang, Y.; Wang, Q.; Deng, Y.; Li, T.; Gruverman, A.; Cao, L.; et al. Monolithic integration of hybrid perovskite single crystals with heterogenous substrate for highly sensitive X-ray imaging. Nat. Photonics 2017, 11, 315-321. [CrossRef]

76. Heiss, W.; Brabec, C. Perovskites target X-ray detection. Nat. Photonics 2016, 10, 288-289. [CrossRef]

77. Liu, Y.; Zhang, Y.; Yang, Z.; Cui, J.; Wu, H.; Ren, X.; Zhao, K.; Feng, J.; Tang, J.; Xu, Z.; et al. Large Lead-Free Perovskite Single Crystal for High-Performance Coplanar X-Ray Imaging Applications. Adv. Opt. Mater. 2020, 8, 2000814. [CrossRef]

78. Yin, L.; Wu, H.; Pan, W.; Yang, B.; Li, P.; Luo, J.; Niu, G.; Tang, J. Controlled cooling for synthesis of $\mathrm{Cs}_{2} \mathrm{AgBiBr}_{6}$ single crystals and its application for $X$-ray detection. Adv. Opt. Mater. 2019, 7, 1900491. [CrossRef]

79. Liu, Y.; Xu, Z.; Yang, Z.; Zhang, Y.; Cui, J.; He, Y.; Ye, H.; Zhao, K.; Sun, H.; Lu, R. Inch-size 0D-structured lead-free perovskite single crystals for highly sensitive stable $X$-ray imaging. Matter 2020, 3, 180-196. [CrossRef]

80. Xu, Z.; Liu, X.; Li, Y.; Liu, X.; Yang, T.; Ji, C.; Han, S.; Xu, Y.; Luo, J.; Sun, Z. Exploring Lead-Free Hybrid Double Perovskite Crystals of (BA) ${ }_{2} \mathrm{CsAgBiBr}_{7}$ with Large Mobility-Lifetime Product toward X-Ray Detection. Angew. Chem. Int. Ed. 2019, 58, 15757-15761. [CrossRef]

81. Zhang, Y.; Liu, Y.; Xu, Z.; Ye, H.; Yang, Z.; You, J.; Liu, M.; He, Y.; Kanatzidis, M.G.; Liu, S. Nucleation-controlled growth of superior lead-free perovskite $\mathrm{Cs}_{3} \mathrm{Bi}_{2} \mathrm{I}_{9}$ single-crystals for high-performance $\mathrm{X}$-ray detection. Nat. Commun. 2020, 11, 2304. [CrossRef]

82. Tao, K.; Li, Y.; Ji, C.; Liu, X.; Wu, Z.; Han, S.; Sun, Z.; Luo, J. A Lead-Free Hybrid Iodide with Quantitative Response to X-ray Radiation. Chem. Mater. 2019, 31, 5927-5932. [CrossRef]

83. Zhang, R.; Mao, X.; Yang, Y.; Yang, S.; Zhao, W.; Wumaier, T.; Wei, D.; Deng, W.; Han, K. Air-Stable, Lead-Free Zero-Dimensional Mixed Bismuth-Antimony Perovskite Single Crystals with Ultra-broadband Emission. Angew. Chem. Int. Ed. Engl. 2019, 58, 2725-2729. [CrossRef] [PubMed] 
84. Li, Z.; Song, G.; Li, Y.; Wang, L.; Zhou, T.; Lin, Z.; Xie, R.J. Realizing Tunable White Light Emission in Lead-Free Indium(III) Bromine Hybrid Single Crystals through Antimony(III) Cation Doping. J. Phys. Chem. Lett. 2020, 11, 10164-10172. [CrossRef] [PubMed]

85. Jing, Y.; Liu, Y.; Jiang, X.; Molokeev, M.S.; Lin, Z.; Xia, Z. Sb 3 + Dopant and Halogen Substitution Triggered Highly Efficient and Tunable Emission in Lead-Free Metal Halide Single Crystals. Chem. Mater. 2020, 32, 5327-5334. [CrossRef] 